\title{
Determinant Behavior Analysis Of Halal Food Purchases Muslim Consumers In Pekanbaru
}

\author{
Eka Nuraini Rachmawati ${ }^{1}$, Susie Suryani ${ }^{2}$ \\ ${ }^{1 \& 2}$ Faculty of Economics, Universitas Islam Riau, Pekanbaru, Indonesia \\ Email: eka.nuraini@eco.uir.ac.id;Email: susie@eco.uir.ac.id
}

\begin{abstract}
Abstrak: Potensi pasar industri halal telah mengalami pertumbuhan yang signifikan seiring dengan meningkatnya antusiasme dan kesadaran religiusitas Muslim saat ini. Mengkonsumsi produk halal tidak hanya dilihat sebagai penerapan ajaran agama, tetapi telah menjadi cara hidup dan gaya hidup bagi sebagian besar umat Islam. Kepastian kehalalan suatu produk merupakan pertimbangan penting bagi konsumen Muslim dalam keputusan pembelian, terutama yang berkaitan dengan makanan. Tujuan dari penelitian ini adalah untuk menganalisis perilaku konsumen Muslim dalam mengkonsumsi makanan halal dan faktor penentunya. Penelitian ini dilakukan di kota Pekanbaru, provinsi Riau. Sampel penelitian adalah konsumen Muslim yang melakukan pembelian makanan halal dalam kemasan, baik makanan yang bisa dimakan langsung atau makanan yang diproses terlebih dahulu. Hasil penelitian menunjukkan bahwa faktor penentu perilaku konsumen Muslim yang mengkonsumsi makanan halal didominasi oleh norma subjektif dan kontrol perilaku persepsi konsumen.
\end{abstract}

Kata Kunci: Consumer Behavior, Halal Food, Muslim 


\section{INTRODUCTION}

In this period, the awareness of Muslims to use halal products greatly increased. Awareness of halal behavior not only increases in terms of using products but also in making business work, monetary, investment and also relationships between humans (socializing).

Halal products are quickly gaining recognition throughout the world as a new standard for human safety and product quality assurance. Products with halal certification are not only more confident to be accepted by Muslim consumers, but also by other religious consumers (Mustafa et al., 2014). This is because in Islam halal food must not only be free from haram elements (forbidden), but also must be tayyib (good), according to the word of Allah in surah Al-Baqarah verses 168 and 172 which means:

"O mankind! Eat of that which is lawful and wholesome in the earth, and follow not the footsteps of the devil. Lo! he is an open enemy for you." (Al-Baqarah: 168).

"O ye who believe! Eat of the good things wherewith We have provided you, and render thanks to Allah if it is (indeed) He Whom ye worship." (AlBaqarah: 172).

The study of consumer behavior towards halal products, especially those related to food and cosmetics, is quite significant. For example, research by Stitou and Rezgui (2012) in Soesilawati (2013) found that out of 223 Muslim communities in France 56\% stated that they would not buy a product if they were hesitant about the product's halalness. The results of the study with similar conclusions were also found in consumers in Malaysia, which can be seen in the research by Asmat et al. (2014) and Alam (2011). Endah (2014), in her research found that subjective norms had the most influence on the attitudes of Muslim consumers in buying halal products.

Some of the research studies found that religiosity has a big role in shaping consumer attitudes towards halal products. The same thing is also found in the results of research by Jumani \& Siddiqui (2012), Ali (2012), Nasrullah (2015), Mahiah Said, et al. (2014) and Lu'liyatul (2018). All research results show that the level of consumer religiosity greatly influences their behavior in consuming halal products.

This is because religion is the main element in life culture that can influence consumer behavior in decisions to make purchases (Delener, 1994; Pettinger, et al., 2004; Sciffmen \& Kanuk, 2008; Shafie \& Otsman, 2006). Although there are very strict religious and legal demands in terms of food, the extent to which people will follow the law, of course it will vary greatly (Soesilawati \& Yuliana, 2012).

In Indonesia the guarantee of halal products is issued by LPPOM MUI in the form of Halal Certification and Halal logo. The halal logo of the MUI contained in each product package is a guarantee for consumers that the product is religious in terms of religion and good in terms of health. For packaged foods, whether they can be directly eaten (snack) or canned food, consumers can easily check the halal of the product through the MUI halal logo printed on the food packaging.

Identifying the determinants of consumer halal behavior remains interesting and significant to do, not only because of the many factors that influence consumer behavior in their decision to consume a product, but also will provide solutions to producers how to increase customer satisfaction. In addition, of course it can influence government policy in 
developing regulations and laws on halal products.

Based on the explanation above, the purpose of this study was to identify and find the determinant factors of purchasing behavior of halal food, especially packaged foods by Muslim consumers in the city of Pekanbaru with the Theory of Planned Behavior (TPB) approach.

\section{LITERATURE REVIEW Halal}

Halal comes from Arabic, namely halla, yahillu, hillan, which means freeing, releasing, solving and allowing (Ensiklopedia Hukum Islam, 2006). In the dictionary of jurisprudence, the word halal is understood as anything that can be done or eaten. This term is not only related to food and beverage problems, but also in business, tourism, fashion and finance.

\section{Halal Labeling Certification}

Halal certification is a written fatwa by MUI which states the halal of a food product in accordance with Islamic law, which aims to provide legal certainty for those who consume it. Halal labeling is the inclusion of a halal statement or statement on product packaging to show that the product referred to as halal product. In Indonesia, the institution that authorizes halal certification is the Indonesian Ulema Council (MUI), which is technically handled by the Institute for the Study of Food Medicine and cosmetics (LPPOM). While halal labeling activities are managed by the Food and Drug Supervisory Agency (BPOM).

\section{Consumer Behavior Analysis}

Consumer behavior is a study that examines how individuals make decisions to spend available and owned resources (time, money, effort) to get goods or services that will later be consumed (Schiffman \& Kanuk, 2005: 9).

\section{Factors That Affect Consumer Behavior}

Consumer behavior such as behavior is generally influenced by cultural, social, personal and characteristic aspects. Cultural factors are considered to have the greatest influence on one's desires and behavior. Religion is a key element in life culture that affects buying behavior and decisions. Religion is a system of beliefs and prakcties by which group of people interprets and responds to what they feel is supernatural and sacred (Johnstone, 1975 cited in Shafie \& Othman, 2008). The difference in the level of religiosity will affect the value system adopted by someone (Mokhlis, 2006).

\section{Theory of Planned Behavior}

The Theory of Planned Behavior is a model that is commonly used to look at the factors that influence consumer purchasing decisions and behavior towards a particular product. According to this theory an action begins with "Intention" where the intention is influenced by three internal factors, namely: Attitude; Subjective Norms; and Perceived Behavioral Control.

Attitudes describe the results of an evaluation of an entity (object or action), whether he likes it or not (Azjen, 1991; Peter dan Jerry, 2005; Mokhlis, 2006).

Subjective norms are individual perceptions of people who are important to themselves towards an object. If attitude is encouraged from the results of selfevaluation, it is different from subjective norms that come from outside influences (normative belief). This makes a social or organizational perspective very influential on the formation of perceptions of a Muslim consumer. The more people who are important for him to recommend buying halal food, he will tend to have more 
intention to buy halal food. This subjective norm will be stronger when a person or consumer is in a more dictatorial situation (Vencantesh \& Davis, 2000).

Muslim consumers who have high religiosity generally tend to have a higher awareness of consuming halal products. In addition, these consumer groups also tend to have strong social ties because the frequency of worshiping in congregation is more frequent so that the greater normative belief in consumers. Previous research on halal products using the TPB model shows that subjective attitudes and norms are factors that significantly influence one's intention to consume halal products (Soesilowati, 2009; Lada et al., 2009; Tarqiainen \& Sundqvist, 2005; Bonne et al., 2010).

Azjen (1991) define the variable perception of behavioral control as how far a person believes or feels capable of doing something. This variable is determined by individual beliefs about both situational strength and internal factors to facilitate behavior. The more a person perceives himself capable then the greater the intensity of a person to do an action. Research conducted by Alam dan Nazura (2011) dan Vencantesh (2000), shows that there is a significant influence on the perception variable of behavior control on the intention to purchase halal products.

The research referred to in this paper focuses on the behavior of Muslim consumers in consuming halal food in packages using the Behavior Theory approach adapted from Planned Behavior Theory. In this theory there are three aspects that determine a person's behavior, namely attitudes, subjective norms and perceptions of behavioral control (Ajzen, 1991)

\section{METHOD}

The data analysis method used in this study is the analysis of Structural Equation Modeling (SEM). To measure the construction of the model, the data used is obtained from the value of question indicators in the questionnaire and processed using the LISREL 8.80 program. The questionnaire uses 5-point Likert-type scales $(1=$ strongly disagree and $5=$ strongly agree). The sampling technique uses Purposive non Probability Sampling with Accindental Sampling techniques. Bentler \& Chon (1987) recommend a ratio of sizes to the number of parameters of 5: 1 . The total number of samples in this study amounted to 163 respondents and the number of parameters in the questionnaire was 29. Thus 163 samples were sufficient.

\section{Results and Discussion Respondents Description}

The summary results of the respondent's description in Table 1 show that, most of them are graduates and have attended religious activities.

Table 20. Summary of respondents description

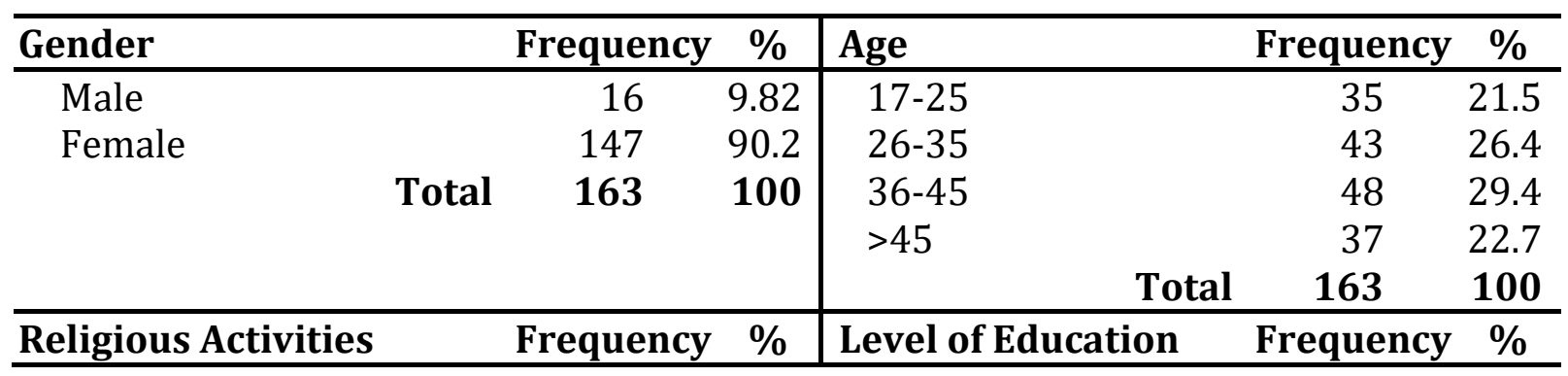




\begin{tabular}{|c|c|c|c|c|c|c|}
\hline Never & & 54 & 33.1 & Secondary Education & 12 & 7.36 \\
\hline 1 in a week & & 59 & 36.2 & Higher Education & 44 & 27 \\
\hline 2 in a week & & 25 & 15.3 & University Degree & 89 & 54.6 \\
\hline 3 in a week & & 9 & 5.52 & Other... & 18 & 11 \\
\hline$>3$ in a week & & 16 & 9.82 & Total & 163 & 100 \\
\hline & Total & 163 & 100 & & & \\
\hline
\end{tabular}

Source: Data processed (2019)

\section{Test of Validity and Reliability}

Questions in the questionnaire were assessed as important parameters for measuring model construction in SEM analysis. So it is necessary to test the validity and reliability of the questions. Based on the results of the LISREL program analysis, each manifest variable has values of standardized loading factor more than 0.5 (Figure 2), so that the questions in the questionnaire are declared valid and acceptable as a model measurement tool. To test the reliability of construction of an instrument seen from the value of Contract Reliability (CR) and Variance Extracted (VE). Based on the calculations that have been done, it is proven that all CR and AVE coefficients for all indicators of latent variables are more than 0.5 . Thus it can be concluded that, all manifest variable indicators are considered reliable.

Figure 3. Path diagram for the estimated model (Standardized Solution)

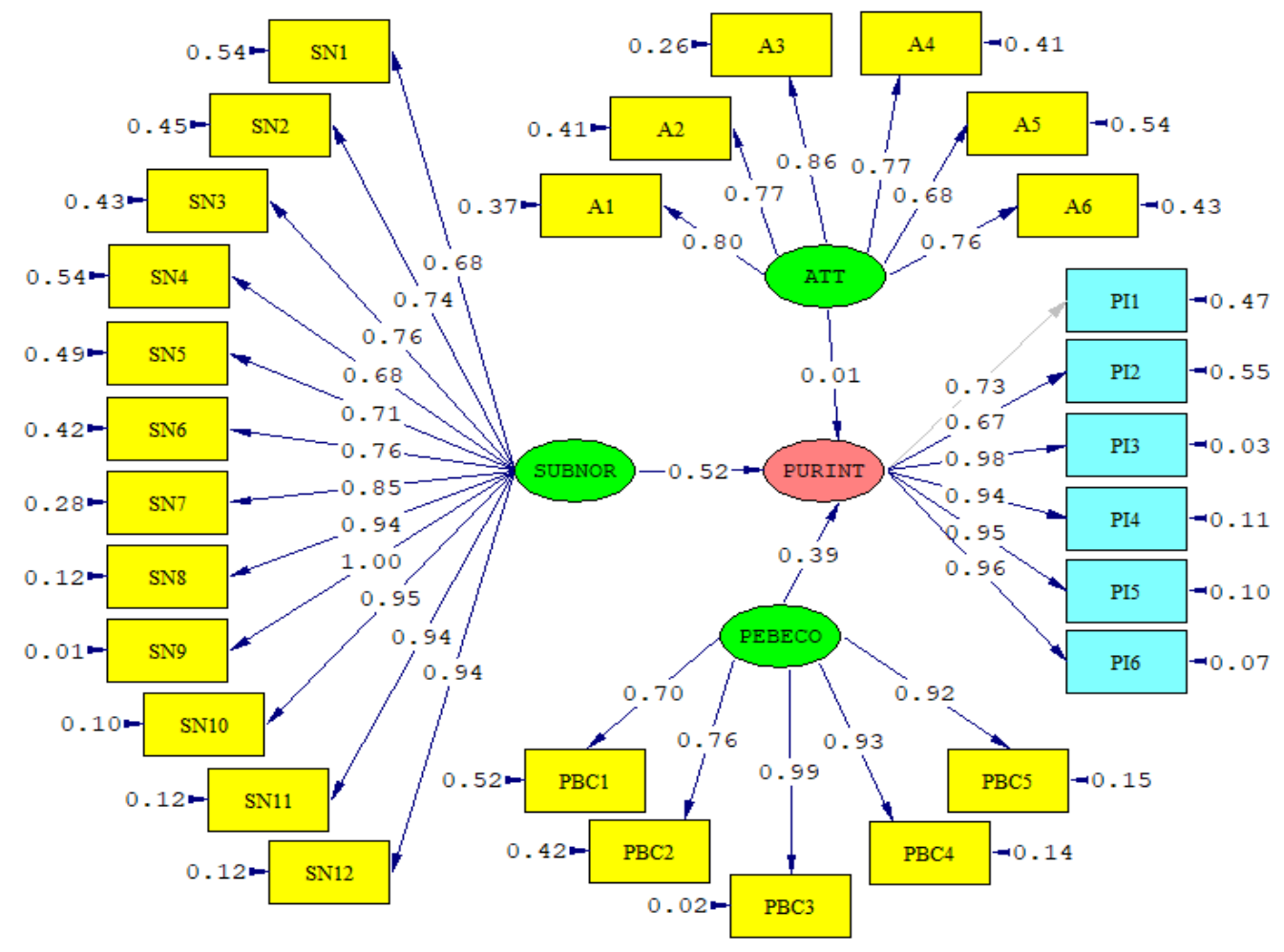

Chi-Square=214.54, $d f=115, \mathrm{P}-\mathrm{value}=0.000, \mathrm{RMSEA}=0.080$ 


\section{Test of Goodness of Fit}

The test of goodness of fit aims to test whether the proposed model is compatible with the sample data or not. A model is said to be appropriate if the sample covariance matrix is not much different from the estimated covariance matrix. The output of the testing of the Theory of Planned Behavior model that has been done can be seen in the following table.

Table 11. Result goodness of fit (GOF)

\begin{tabular}{|c|c|c|c|}
\hline GOF Measures & Estimation Results & $\begin{array}{c}\text { Model Evaluation } \\
\text { Procedure } \\
\end{array}$ & Description \\
\hline Statistics $x^{2}$ & $\begin{array}{l}\mathrm{df}=115 \\
x^{2}=247.88\end{array}$ & $\begin{array}{l}-0 \leq x^{2} \leq 2 \mathrm{df} \\
-2 \mathrm{df} \leq x^{2} \leq 3 \mathrm{df}\end{array}$ & Fit \\
\hline p-Value & 0.000 & $\begin{array}{l}\text { - } 0.05 \leq p \leq 1.00 \\
\text { - } 0.01<p \leq 0.05\end{array}$ & Not Fit \\
\hline RMSEA & 0.080 & $\begin{array}{l}\text { - } \text { RMSEA } \leq 0.08 \\
\text { - } R M S E A \leq 0.05\end{array}$ & Fit \\
\hline NFI & 0.97 & $\begin{array}{l}\text { NFI }>0.90 \\
\text { - } 0.80<\mathrm{NFI}<0.90\end{array}$ & Fit \\
\hline CFI & 0.98 & $\begin{array}{l}\text { - } \mathrm{CFI}>0.97 \\
\text { - } 0.90<\mathrm{CFI}<0.97\end{array}$ & Fit \\
\hline GFI & 0.85 & $\begin{array}{l}\text { - } \mathrm{GFI}>0.90 \\
\text { - } 0.80<\mathrm{GFI}<0.90\end{array}$ & Fit \\
\hline AGFI & 0.92 & $\begin{array}{l}\text { - AGFI > } 0.89 \\
0.80<\text { RFI < } 0.89\end{array}$ & Fit \\
\hline
\end{tabular}

Source: Processed Data by LISREL 8.80 (2019)

Based on the results of the analysis above, the fact that the results of the Goodness of Fit (GOF) are generally categorized as fit, only one parameter is not fit. It can be concluded that the model is quite fit, meaning that the sample covariance matrix is relatively the same as the estimates covariance matrix. Thus $\mathrm{H}_{1}$ is acceptable. 


\section{Hypothesis Test}

Figure 4. Path diagram for the estimated model (t-values)

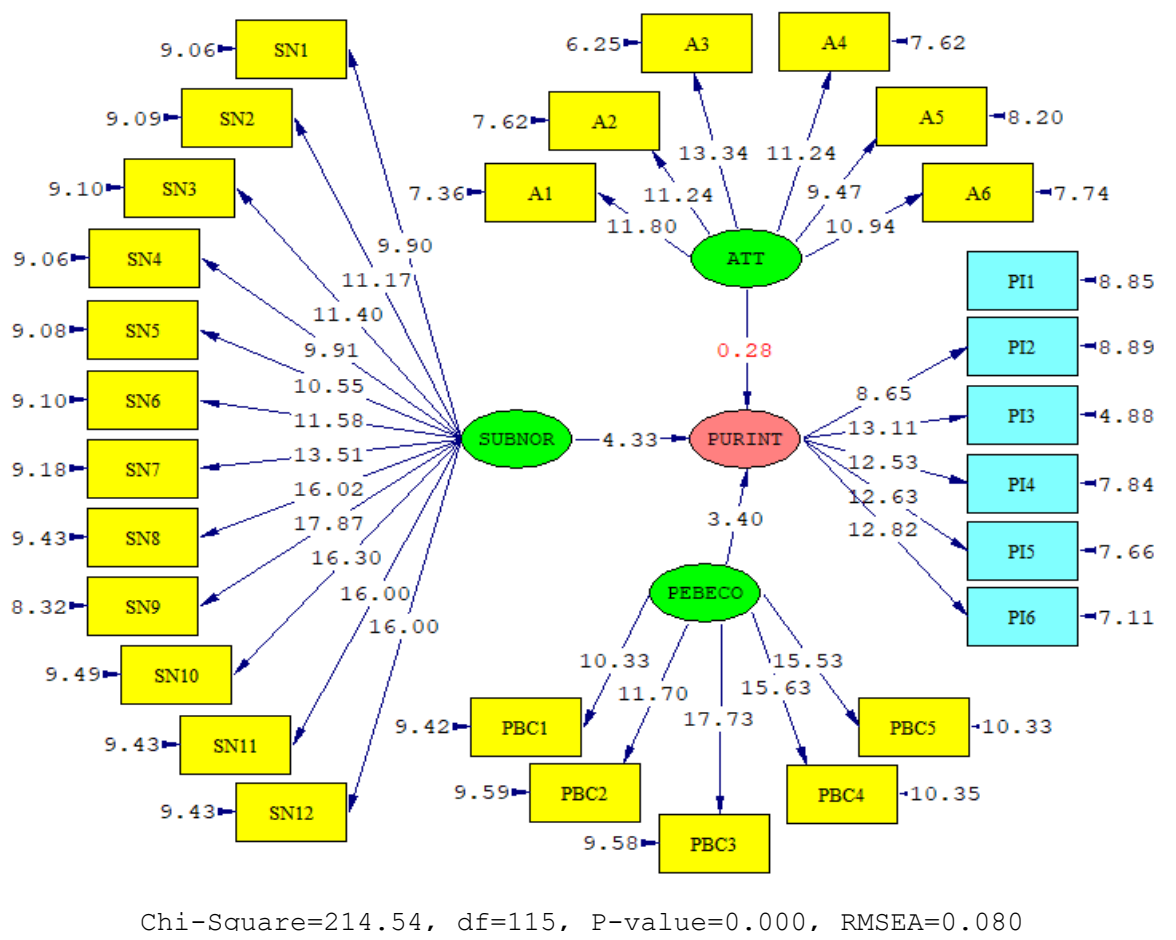

Figure 3 above shows the results of Behavioral Control) with endogenous measurement of hypothesis testing variables (Purchase Intention). The between exogenous variables (Attitude; conclusion of the hypothesis testing can be Subjective Norms; and Perceived seen in the following table.

Table 22. Result of hypothesis test

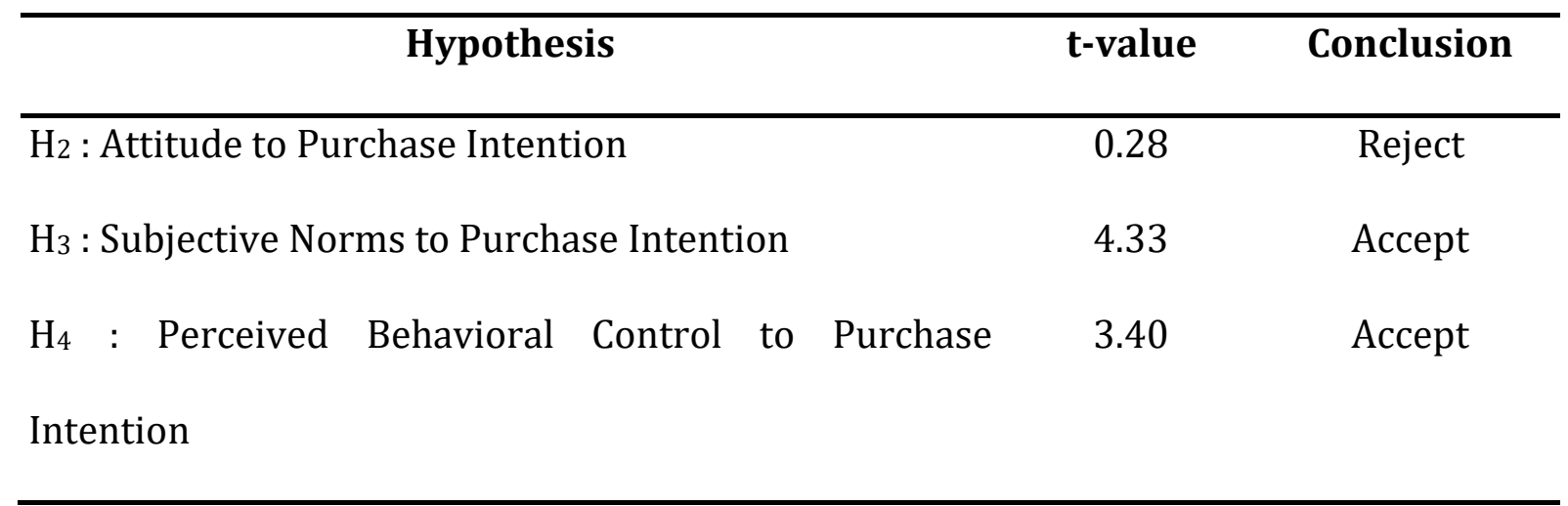

\section{Source: Data processed (2019)}

Based on the results of the analysis using the LISREL program, it was found that the second hypothesis was not acceptable. Where this means, the attitude of a Muslim does not affect the decision to buy halal products. The rejection of the hypothesis shows a difference in previous research on halal products using the TPB model, which shows that subjective attitudes and norms are significant factors 
that influence Muslim's intention to consume halal products (Soesilowati, 2009; Lada et al., 2009; Tarqiainen \& Sundqvist, 2005; Bonne et al., 2010).

This study produced conclusions that were different from the results of several previous studies, which also used the Theory of Planned Behavior model. This may be influenced by a small number of samples, or influenced by several other factors, so there needs to be further testing to ascertain the results of this study.

\section{Conclusion}

Based on the results of analysis of structural equation modeling that was processed using the LISREL program, it can be concluded that the attitude of Muslim consumers towards the halalness of a product does not affect the product purchasing decision. However, the intensity of Muslim consumer purchases of halal products is influenced by subjective norms and perceived behavioral control.

\section{References}

Alam, S.S., Mohd, R., Hisham, Badrul. (2011). Is religiosity an important determinant on muslim consumer behaviour in malaysia?. Journal of Islamic Marketing, Vol. 2, Issue: 1, pp. 83-96. doi: 10.1108/17590831111115268

Ali, Yunus. (2012). Halal Branding: A Study of Moslem Consumers Perspective. On Proceeding of The 2nd Global Islamic Marketing Conference, Abu Dhabi. pp.1-6

Asmat. Nizam Abdul, Talib and lli Salsabila Abd. Razak, "Cultivating Export Market Oriented Behavior in Halal Marketing" Konsep Strategi Pemasaran Global yang Berorientasi pada Prilaku Halal www.emeraldnsighr.com/17590833.htm
Asmak, A., Fatimah, S., Huzaimah, I., et al. (2015). Is our Medicine Lawful (Halal)?. Middle-East Journal of Scientific Research 23 (3): 367-373, 2015 ISSN 1990-9233. Retrieved February 23, 2018, from https://www.idosi.org/mejsr/me jsr23(3)15/1.pdf

Ensiklopedi Hukum Islam. (2006). PT. Ichtiar Baru Van Hoeve, Jakarta.

Halim, M. A. A., Salleh, M. M. M., et al. (2014). Halal Pharmaceuticals: Legal, Shari'ah Issues And Fatwa Of Drug, Gelatine And Alcohol. International Journal of Asian Social Science ISSN (e): 2224-4441, 2014. Retrieved February 23, 2018, from http://www.aessweb.com/pdffiles/ijass-2014-4(12)-1176-1190.pdf Husin, N. A., Ghazali, A. S.M., et al. (2015). Halal Medicine: Do Doctors Have The True Awareness?. IJABER, Vol. 13, No. 7 (2015): 5173-5184. Retrieved February 23, 2018, from https://www.researchgate.net/ publication/302192031 Halal medici ne Do doctors have the true awaren $\underline{\text { ess }}$

Kepastian Hukum Sertifikasi dan Labelisasi Halal Produk Pangan KN.Sufyan Hasan, Jurnal Dinamika Hukum Vol.14 No.2 Mei 2014 Univ. Sriwijaya Palembang

Mohd. Anuar Ramli, Mohammad Aizat Jamaludin, Abdul QayyumAminuddi dan Mohammad Nagib Hamdan, "Penyebaran Maklumat Palsu Berkaitan Produk Halal dan Implakasinya Terhadap Industri Halal Muhammad Arham, "Islamic Perspectives on Marketing" Pengaplikasian marketing syariah. from www.emeraldnsighr.com/17590833.htm 
Muhammad Nasrullah; Islamic Branding, Religiositas dan Keputusan Konsumen terhadap Produk ; Jurnal Hukum Islam (JHI), Vol.13 No.2 Desember 2015 (79-87)

Ahsin, Muhammad Sakho. (2009). Ensiklopedia Kemukjizatan Ilmiah dan Al-Quran dan Sunah. PT.Kharisma Ilmu, Jakarta.

Nur Hadiati Endah (Pusat Penelitian Ekonomi LIPI), "Perilaku Pembelian Kosmetik Berlabel Halal dengan Konsumen Indonesia" , Jurnal Ekonomi dan Pembangunan Vol.22 No.1 , 2014

Sadeeqa, Saleha., Sarriff, Azmi. (2014). Comparing KAP regarding Halal pharmaceuticals among general practitioners and hospital doctors. Journal of Applied Pharmaceutical Science Vol. 4 (10), pp. 092-096. Retrieved February 23, 2018, from http://japsonline.com/admin/php/u ploads/1356 pdf.pdf

Sarriff, Azmi., Razzaq, Hadeer, A. A. (2012). Exploring the Halal Status of Cardiovascular, Endocrine, and Respiratory Group of Medications. Malays J Med Sci. Jan-Mac 2013; 20(1): 69-75. Retrieved February 23, 2018, from https://www.ncbi.nlm.nih.gov/pubm ed/23785257

Syaamil Al-Qur'an. (2010). Miracle The Reference (Mudah, Sahih, Lengkap dan Komprehensif). Sygma Publishing, Bandung. 